\title{
Identification of Student-Teachers Groups' Needs in Physical Education and Sport for Designing an Open Distance Learning on the Model of Small Private Online Courses
}

\author{
Mostafa HAMSE ${ }^{1}$, Mohammed TALBI ${ }^{3}$ \\ Laboratory of Analytical Chemistry and Physio Chemistry \\ of Materials, Observatory of Research in Didactics and \\ University Pedagogy, Faculty of Sciences Ben M'SIK \\ Hassan II University, Casablanca, Morocco
}

\author{
Said LOTFI $^{2}$ \\ Multidisciplinary Laboratory in Education Sciences and \\ Training Engineering, Normal Superior School (ENS) \\ Hassan II University, Casablanca, Morocco
}

\begin{abstract}
Currently, there are witnessing several distancelearning offerings: FOAD (Open Distance Learning) MOOCs (Massive Open Online Course) and SPOCS (Small Private Online Courses) in various intervention sectors including education and training. However, little research has dealt with analyzing the needs of participants before implementing SPOCs in higher education. This study aims to identify needs in order to design and guide a technopedagogical device in SPOCs' form for teacher training.The results showed that more than $70 \%$ of interviewees declared that SPOC reduces participants' travel time, $87 \%$ aimed at developing professional competence in planning learning, $77 \%$ wanted students' evaluation and more than $60 \%$ wanted to know the disciplinary knowledge relating to physical and sporting activities (PSA) and their Learning activities' management.In addition, $64.3 \%$ of participants preferred, as device's form and design, the four modalities at the same time: text structured in title, video capsules, images and sound recording. In terms of educational tutoring, more than 75\% of participants declared their need to understand certain concepts in the course. These results will guide us to focus attention on three basic professional skills: planning, management and evaluation of learning as a priority training module in the envisaged SPOC with technical and pedagogical support both audiovisual and textual.
\end{abstract}

Keywords-Needs; physical education and sport; professional training; SPOC; teachers

\section{INTRODUCTION}

Several descriptive studies have shown that information and communication technologies (ICT) are experiencing remarkable expansion in various sectors of society: economic, political, social, cultural and the education and training sector ( Traoré, 2008; Redecker et al., 2009; Biaz et al., 2009; Maddux et al., 2012; Collin, et al., 2013; Ait Kaikai, 2014) [1]-[6]. Information and Communication (ICT) is defined by (UNESCO 2006) [7] as a form of technology used to transmit, store, create, share or exchange information.This broad definition of ICT includes technologies such as: radio, television, video, DVD, telephone (both landline and mobile), satellite systems, computer and network hardware and software, and associated equipment and services technologies, such as video, in addition to the equipment and services associated with these technologies, such as videoconferencing and electronic mail.

In this regard, in Morocco, the strategic vision of the 20152030 reform continues to proclaim capital importance to the integration of ICTs for the development and promotion of digital-based education and training through the implementation of adapted, scalable, open and innovative systems. In addition, and with the aim of strengthening the integration of educational technologies to improve the quality of learning and to promote the transition from a knowledgeconsuming society to a society that produces and disseminates it, the Superior Council of the Education, Training and Scientific Research (CETSR) [8] recommends developing a national program, aiming to complete the equipment of educational establishments with educational technologies, multimedia rooms and audiovisual equipment, to connect them to the network internet and to equip school libraries and university research structures with the necessary digital resources, medium-term integration of ICT as the main subject in initial and continuing training of all educational actors and the development and promotion of distance learning as a complement to face-to-face courses. Otherwise, some studies have concluded that, the lack of teachers' training (initial or / and continuous) in terms of digital tools' use, the deficiency in the educational exploitation of ICT and individual factors are the main obstacles linked to the integration of ICT in Morocco's classroom (El Ouidadi et al. (2011) [9].Nevertheless, the operationalization of these recommendations requires on part of all actors intervening in the field of education and training a specific mobilization based on collaborative work which highlights an administrative will, an educational and multimedia design in order to carry out this quest to integration ICT in education and training in Morocco.

In this context, the professional training of future teachers of Physical and Sports Education (PSE) at the Regional Center of Education and Training Professions (RCETP) CasablancaSettat, adhered to this vision by taking advantage of the 
structuring characteristics, organization and adaptation offered by Open and Distance Learning (ODL) to offer them an ODL on the model of SPOCs (Small Private Online Courses) for completing, on the one hand, their initial training in face to face, and on the other hand, for further developing their professional teaching skills [10].However, recourse to the use of this distance training device in vocational training requires a particular educational, multimedia and organizational design [11]. Therefore, we refer in the design of our SPOC to training engineering by referring to the ADDIE Model (Analysis, Design, DevelopmentImplementation and Evaluation) which is very well known worldwide in training engineering and ODL design. This model is presented in 4 steps: Analysis, Design, Realization and Evaluation [12]. In this engineering, the analysis of training needs represents an essential key to the training design, because it provides the elements of orientation, planning and strategy, which are necessary for the formulation of effective learning objectives that contribute to a best performance [13].

In this study, we focus on the first step reserved for the participants' needs analysis for the establishment of an ODL device based on SPOCs envisaged.

The objective of this study is to identify the studentteachers groups' needs in terms of skills, design and educational tutoring, to guide a future design of this technopedagogical device.

\section{THEORETICAL BACKGROUND}

\section{A. ICT and its uses}

The Organization for Economic Co-operation and Development (OECD) (2001, 2006) [14]-[15] stresses the economic importance and impact of ICT in developed countries and stresses the need for these countries to train a workforce with the skills necessary to use ICTs to increase productivity, as well that the need for young people to develop ICT skills for possible preparation for adult life.In this regard, many researches have concluded that, ICT has become an essential way in improving the quality of learning. Indeed, for Basque et al., 2003; Mastafi (2013) [16]-[17] these technologies, when combined and interconnected, make it possible to search for, store, process and disseminate an impressive amount of information, in the form of different data types (text, sound, images, simulations, etc.), and can be used to exchange, communicate, collaborate, cooperate, produce, create and publish.In addition, the integration of ICT brings several benefits such as flexibility, accessibility, increased exchanges and interactions between various actors (Karsenti, 2003; Nafidi et al., 2015) [18]-[19]. ICTs delocalize, in time and space, the exchanges between teachers and learners, and thereby diversify learning activities and teaching and learning methods (Peraya, 2006; Depover et al ., 2007) [20]-[21] .Likewise, Cleary et al. [22] analyzed determining factors of ICT's integration in the classroom and They distinguished five factors which favor this integration and which have a positive impact on students' academic results: Training, environmental context, individual variables, the importance of a community and a human support network and the time that one is willing to devote for it.
On the other hand, it's observed in recent years an ICT explosion and a diversity of distance learning platforms, MOOCs (Delpeyroux et al., 2015) [23], the appearance of mobile devices such as smartphones, tablets and other mobile devices and the social media revolution like Facebook, Viadeo, LinkedIn, Twitter, have become very effective means to allow learners who have not had the chance to register in one of the best universities in the world to take advantage of distance course content to learn and improve their knowledge (Riyami 2018) [24]. In short, ICT has opened up new horizons and has enabled a vital development of this type of education [25]. However, the successful integration of ICT into education requires that teachers be well equipped with the methods necessary for a rational and effective use of these technologies in the teaching-learning process (Ahaji, 2012) [26].Otherwise, ICT is also of great interest to teachers.Indeed, the study conducted by Neema-Abooki and Nakintu (2015) [27] reveals that it is urgent that teachers have sufficient knowledge of ICT to have a competitive advantage in the world of education today.Thus (Sumande, 2016) [28] stipulates that distance education and learning in the $21 \mathrm{st}$ century requires both teachers and students to have a little mastery of ICT because this is due to modern teaching methodologies introduced in distance education. Similarly, for Sandholts, Ringstaff and Dwyer (1997), ICTs trigger change in teaching methods and could even pretend to facilitate the transition from the traditional method to the new method of learning using knowledge-building situations [29].Similarly, these ICTs offer teachers several opportunities that can complement and reinforce their face-to-face lessons. Guay (2001) [30] proposes a taxonomy of four educational activities favored by ICT: demonstration, simulation, exercise and communication activities. In this perspective, they would contribute to the development of distance education and increased access to different international networks and online resources [31].

\section{B. ICT and Classeroom's Integration}

According to Mc Gorry [32], the use of ICT can encourage distance education by overcoming the problems linked to cost, to the reduction of the number of teachers. However, these strengths of ICT for teachers remain dependent on their motivation and acceptance of change. For their part, Aziz Rasmy and Thierry Karsenti [33], according to their study on the motivation of teachers in the context of continuous professional development linked to the integration of technologies, note that the feeling of lack of ICT skills pushes teachers to resist change and commitments in carrying out their various tasks. Martine Leclerc (2007) [34] concludes in her study on the profiles of teachers facing the integration of ICT that those who resist "fiercely ICT integration "have a very negative representation. In fact, not only are they not convinced of the educational benefits of ICT, but they consider that these technologies have no benefit and constitute an "unnecessary burden for the teacher".

In this context, the integration of ICT is a systemic process (Depover and Strebelle, 1997) [35].The adoption of ICT by teachers represents the ultimate outcome of this process, but also an immense challenge (Hutchison and Reinking, 2011; Karsenti and Collin, 2013; Livingstone 2012) [36]-[37]-[38], 
despite the ubiquity of technologies in our society (Ertmer and Ottenbreit-Leftwich, 2010; Thibert, 2012). Indeed, for a sustainable and effective integration of ICT in the classroom, it is necessary to follow a multidimensional approach focused on technological equipment, integration content and teacher training. In this sense, Biaz et al. [3] studied the integration of ICT in the work of teachers and stressed the importance of teacher training in the optimal use of ICT for improving the quality of teaching and learning ease of students. Thus, Bibeau in 2007 [39] studied on his side the conditions that can act on the integration of ICT's success in education in general and concluded that ICT improves the motivation of students and allows the development of operations higher order cognitive. This has been confirmed by Labrique [40] that these digital tools can facilitate the rapid acquisition of high-level skills. Nevertheless, and despite these conditions, the integration of ICT is faced with other difficulties, among others, the low confidence of teachers in the effectiveness of ICT for teaching and for student's learning. Like Tardif (1998) [41] and Lebrun (2002) [42], teachers would need to know the relevance of integrating ICT for their teaching a better learning.

\section{Barriers of ICT's Integration}

The difficulties or obstacles linked to the integration of ICT by teachers seem to come from several sources that can be grouped into two main categories: external factors (linked to school, society, etc. .) and internal factors (linked to the teacher or teaching) (Karsenti and Gauthier 2006) [43]. For these authors, the equipment of establishments presents a main external obstacle.For Ertmer, P. (1999) [44], the non-use of ICT by teachers is due to internal factors, in this case, their attitudes, beliefs, practices and resistance to change. Thus, Pelgrum, WJ (2001 ) [45] mentions, as internal and immaterial obstacles, the insufficient knowledge and skills of teachers in the field of ICT, the difficulty of integrating the use of ICT in teaching and the insufficient time of teachers.Similarly, the British Educational Communications and Technology Agency (BECTA, 2005) [46] and the OECD (2004) [9] emphasize that when the school culture is inadequate, it slows down the integration of ICT by teachers. The internal factors blocking the integration of ICT by teachers are lack of time, poor feeling of technopedagogical competence or self-efficacy, anxiety, difficulties related to class management and motivation or attitudes towards the use of ICT.

However, it should be noted that these barriers revealed by the research literature are structural only in relation to the school and the teacher, while there are other functional obstacles which are mentioned in the literature, namely class management skills, weak administrative support, poor school funding and inadequacy with the school curriculum (AlAlwani, 2005; Balanskat et al. 2006; Becta, 2004; Beggs, 2000; Gomes, 2005; Lazaros and Rogers, 2006; Schoepp, 2005) [47]-[48]-[49]-[50]-[51]-[52]-[53].

\section{METHODS}

\section{A. Sample}

Our sample is made up of 70 student teachers, including 19 students in vocational training, all of whom are in vocational training at the Regional Center for Education and Training Professions Casablanca-Settat (RCETP), during the 2018/2019 period, Physical and Sports Education (EPS) intended for teaching at the middle and qualifying school. It is divided into two groups:

A group with hybrid training: formed by 44 studentteachers $(62.9 \%)$ whom we called hybrid in reference to the nature of the ODL received.They undergo a dual initial training: face-to-face at RCETP and online training through an ODL-SPOC device called FP@STAPS, hosted on a MOODLE Version 3.2 platform, a Learning Management System which used to create and distribute dynamic interactive online courses [54]. - A group with distant training formed by 26 student-teachers of the 2017 training promotion who practice their profession in practice and undergo face-toface training at RCETP spread over 4 weeks of reception, training and evaluation.

\section{B. Measuring Instruments}

In the present survey, we administered a questionnaire to two groups in our sample, in order to collect the following parameters:

- Perceptions of SPOCs' interest.

- The professional skills expected from the FP@STAPS system.

- Design needs for training content, and educational tutoring.

This questionnaire composed of closed questions of dichotomous type and multiple choice.

\section{Data Analysis}

The data are analyzed by ANOVA I, Khi 2 ( $\mathrm{p}<0.05)$ by comparing the variables' frequencies, and we examined the effect of the group on the following variables: the perceptions' scale of SPOCs, professional skills targeted by studentteachers, expected forms of FP@STAPS content and educational tutoring needs, with the significance level defined at $\mathrm{p}<0.05$. The data was processed with SPSS software.

\section{RESULTS}

The results on the SPOCs' perceptions of trainees are presented in Table I, the professional skills expected by the participants are presented in Table II, and for the design (or form) needs of FP@STAPS and educational tutoring are presented respectively in Tables III and IV.

\section{A. Perceived Interest in SPOCs}

Analysis of data relating to student-professors' perceptions of SPOC, shows that $77.1 \%$ of those interviewed showed the importance of SPOC, including the reduction in travel time of participants, the decrease in contacts with learners $(30.0 \%)$, individualized follow-up through a SPOC (21.4\%); the feasibility of a face-to-face course compared to a SPOC (10.0\%).Furthermore, the analysis of the data presented in Table I does not indicate any significant difference between the groups in all the parameters of the SPOCs' interest perception. 


\section{B. Professional Skills Related PES Teaching Expected by} Students via an ODL-SPOC "FP@STAPS"

From Table II, we can notice that all of the studentteachers do not perceive that SPOCs allow the development of the following professional skills: planning of learning, evaluation of students, design of a training plan, disciplinary knowledge relating to physical and sports activities (PSA).

However, the learning management skill is the only skill perceived to be developed by the SPOCs by $62.9 \%$ of studentteachers. Our results showed that there is no significant difference between the two groups.

\section{Design (or form) needs of "FP@STAPS"}

The form of content preferred by the students towards FP@STAPS device varies between text structured in titles, video sequences, images and sound recording. In fact, $64.3 \%$ of student-teachers prefer the four modalities at the same time (Table III). No significant difference was observed between the two groups at this level.

\section{Needs Related to Educational Tutoring}

The educational tutoring needs expressed by studentteachers relate to: the explanation of certain course concepts (77.1\%), resolution of technical problems related to the platform (68.6\%), highlighting the activities' objectives (38.6\%), and works' assessment (34.3\%).

It is also noted that the dependence of all the needs related to educational tutoring and student-teachers' group type is statistically insignificant. However, we have noticed that the hybrid group needs significantly more explanation of objectives than the distant group.

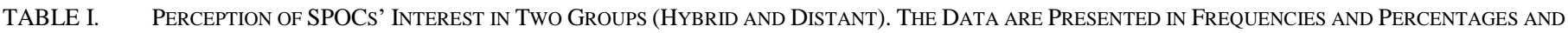
COMPARED BY THE CHI-SQUARE TEST

\begin{tabular}{|c|c|c|c|c|c|c|c|c|c|c|}
\hline & & & & & & & & Chi & to & \\
\hline & & & & Dis & nced & Tot & & Cim-sy & IE & \\
\hline & & $\mathrm{N}$ & $\%$ & $\mathrm{~N}$ & $\%$ & $\mathrm{~N}$ & $\%$ & Khi2 & dll & $\mathrm{p}$ \\
\hline $\begin{array}{l}\text { SPOC is easier than a face-to-face course } \\
\text { at RCETP }\end{array}$ & $\begin{array}{l}\text { By no means agree } \\
\text { Little agree } \\
\text { Moderately agree } \\
\text { Somewhat agree } \\
\text { Totally agree }\end{array}$ & $\begin{array}{l}1 \\
11 \\
23 \\
7 \\
2\end{array}$ & $\begin{array}{l}1.4 \% \\
15.7 \% \\
32.9 \% \\
10.0 \% \\
2.9 \%\end{array}$ & $\begin{array}{l}2 \\
3 \\
11 \\
8 \\
2\end{array}$ & $\begin{array}{l}2.9 \% \\
4.3 \% \\
15.7 \% \\
11.4 \% \\
2.9 \%\end{array}$ & $\begin{array}{l}3 \\
14 \\
34 \\
15 \\
4\end{array}$ & $\begin{array}{l}4.3 \% \\
20.0 \% \\
48.6 \% \\
21.4 \% \\
5.7 \%\end{array}$ & 4.902 & 4 & 0.297 \\
\hline $\begin{array}{l}\text { The SPOC allows individualized follow- } \\
\text { up and teaching }\end{array}$ & $\begin{array}{l}\text { By no means agree } \\
\text { Little agree } \\
\text { Moderately agree } \\
\text { Somewhat agree } \\
\text { Totally agree }\end{array}$ & $\begin{array}{l}0 \\
1 \\
12 \\
18 \\
13\end{array}$ & $\begin{array}{l}0.0 \% \\
1.4 \% \\
17.1 \% \\
25.7 \% \\
18.6 \%\end{array}$ & $\begin{array}{l}1 \\
2 \\
8 \\
13 \\
2\end{array}$ & $\begin{array}{l}1.4 \% \\
2.9 \% \\
11.4 \% \\
18.6 \% \\
2.9 \%\end{array}$ & $\begin{array}{l}1 \\
3 \\
20 \\
31 \\
15\end{array}$ & $\begin{array}{l}1.4 \% \\
4.3 \% \\
28.6 \% \\
44.3 \% \\
21.4 \%\end{array}$ & 6.829 & 4 & 0.145 \\
\hline $\begin{array}{l}\text { The SPOC reduces the participants' } \\
\text { travel time }\end{array}$ & $\begin{array}{l}\text { By no means agree } \\
\text { Little agree } \\
\text { Moderately agree } \\
\text { Somewhat agree } \\
\text { Totally agree }\end{array}$ & $\begin{array}{l}2 \\
0 \\
3 \\
7 \\
32\end{array}$ & $\begin{array}{l}2.9 \% \\
0.0 \% \\
4.3 \% \\
10.0 \% \\
45.7 \% \\
\end{array}$ & $\begin{array}{l}2 \\
0 \\
0 \\
2 \\
22\end{array}$ & $\begin{array}{l}2.9 \% \\
0.0 \% \\
0.0 \% \\
2.9 \% \\
31.4 \%\end{array}$ & $\begin{array}{l}4 \\
0 \\
3 \\
9 \\
54\end{array}$ & $\begin{array}{l}5.7 \% \\
0.0 \% \\
4.3 \% \\
12.9 \% \\
77.1 \%\end{array}$ & 3.214 & 3 & 0.360 \\
\hline $\begin{array}{l}\text { In a face-to-face course, I am more often } \\
\text { in contact with other learners compared } \\
\text { to a SPOC }\end{array}$ & $\begin{array}{l}\text { By no means agree } \\
\text { Little agree } \\
\text { Moderately agree } \\
\text { Somewhat agree } \\
\text { Totally agree }\end{array}$ & $\begin{array}{l}1 \\
5 \\
12 \\
15 \\
11\end{array}$ & $\begin{array}{l}1.4 \% \\
7.1 \% \\
17.1 \% \\
21.4 \% \\
15.7 \%\end{array}$ & $\begin{array}{l}0 \\
4 \\
3 \\
9 \\
10\end{array}$ & $\begin{array}{l}0.0 \% \\
5.7 \% \\
4.3 \% \\
12.9 \% \\
14.3 \%\end{array}$ & $\begin{array}{l}1 \\
9 \\
15 \\
24 \\
21\end{array}$ & $\begin{array}{l}1.4 \% \\
12.9 \% \\
21.4 \% \\
34.3 \% \\
30.0 \%\end{array}$ & 3.673 & 4 & 0.452 \\
\hline $\begin{array}{l}\text { The face to face course at RCETP is more } \\
\text { prestigious than a SPOC }\end{array}$ & $\begin{array}{l}\text { By no means agree } \\
\text { Little agree } \\
\text { Moderately agree } \\
\text { Somewhat agree } \\
\text { Totally agree }\end{array}$ & $\begin{array}{l}1 \\
4 \\
22 \\
11 \\
6\end{array}$ & $\begin{array}{l}1.4 \% \\
5.7 \% \\
31.4 \% \\
15.7 \% \\
8.6 \%\end{array}$ & $\begin{array}{l}3 \\
2 \\
12 \\
8 \\
1\end{array}$ & $\begin{array}{l}4.3 \% \\
2.9 \% \\
17.1 \% \\
11.4 \% \\
1.4 \%\end{array}$ & $\begin{array}{l}4 \\
6 \\
34 \\
19 \\
7\end{array}$ & $\begin{array}{l}5.7 \% \\
8.6 \% \\
48.6 \% \\
27.1 \% \\
10.0 \%\end{array}$ & 4.309 & 4 & 0.366 \\
\hline
\end{tabular}


TABLE II. The Professional SKILls TARgETED by SPOCs ACCORDING TO STUDENT-TEACHERs.DATA ARE PRESENTED IN FREQUENCIES AND PERCENTAGES AND COMPARED BY THE CHI-SQUARE TEST

\begin{tabular}{|c|c|c|c|c|c|c|c|c|c|c|}
\hline & \multicolumn{6}{|c|}{ Group } & \multirow{2}{*}{\multicolumn{3}{|c|}{ Chi-square test 2}} \\
\hline & & \multicolumn{2}{|c|}{ Hybrid } & \multicolumn{2}{|c|}{ Distanced } & \multicolumn{2}{|c|}{ Total } & & & \\
\hline & & $\mathrm{N}$ & $\%$ & $\mathrm{~N}$ & $\%$ & $\mathrm{~N}$ & $\%$ & Khi2 & dll & $\mathrm{p}$ \\
\hline Learnings' planning & $\begin{array}{l}\text { By no means agree } \\
\text { Little agree } \\
\text { Moderately agree } \\
\text { Somewhat agree } \\
\text { Totally agree }\end{array}$ & $\begin{array}{l}4 \\
40 \\
0 \\
0 \\
0\end{array}$ & $\begin{array}{l}5.7 \% \\
57.1 \% \\
0.0 \% \\
0.0 \% \\
0.0 \%\end{array}$ & $\begin{array}{l}5 \\
21 \\
0 \\
0 \\
0\end{array}$ & $\begin{array}{l}7.1 \% \\
30.0 \% \\
0.0 \% \\
0.0 \% \\
0.0 \%\end{array}$ & $\begin{array}{l}9 \\
61 \\
0 \\
0 \\
0\end{array}$ & $\begin{array}{l}12.9 \% \\
87.1 \% \\
0.0 \% \\
0.0 \% \\
0.0 \%\end{array}$ & 1.500 & 1 & 0.221 \\
\hline Managing learning activities & $\begin{array}{l}\text { By no means agree } \\
\text { Little agree } \\
\text { Moderately agree } \\
\text { Somewhat agree } \\
\text { Totally agree }\end{array}$ & $\begin{array}{l}0 \\
0 \\
0 \\
44 \\
0 \\
\end{array}$ & $\begin{array}{l}0.0 \% \\
0.0 \% \\
0.0 \% \\
62.9 \% \\
0.0 \% \\
\end{array}$ & $\begin{array}{l}5 \\
21 \\
0 \\
0 \\
0\end{array}$ & $\begin{array}{l}7.1 \% \\
30.0 \% \\
0.0 \% \\
0.0 \% \\
0.0 \%\end{array}$ & $\begin{array}{l}5 \\
21 \\
0 \\
44 \\
0\end{array}$ & $\begin{array}{l}7.1 \% \\
30.0 \% \\
0.0 \% \\
62.9 \% \\
0.0 \%\end{array}$ & 70.000 & 2 & 0.000 \\
\hline Evaluating students & $\begin{array}{l}\text { By no means agree } \\
\text { Little agree } \\
\text { Moderately agree } \\
\text { Somewhat agree } \\
\text { Totally agree }\end{array}$ & $\begin{array}{l}10 \\
34 \\
0 \\
0 \\
0\end{array}$ & $\begin{array}{l}14.3 \% \\
48.6 \% \\
0.0 \% \\
0.0 \% \\
0.0 \% \\
\end{array}$ & $\begin{array}{l}6 \\
20 \\
0 \\
0 \\
0 \\
\end{array}$ & $\begin{array}{l}8.6 \% \\
28.6 \% \\
0.0 \% \\
0.0 \% \\
0.0 \% \\
\end{array}$ & $\begin{array}{l}16 \\
54 \\
0 \\
0 \\
0\end{array}$ & $\begin{array}{l}22.9 \% \\
77.1 \% \\
0.0 \% \\
0.0 \% \\
0.0 \% \\
\end{array}$ & 0.001 & 1 & 0.973 \\
\hline $\begin{array}{l}\text { Knowing the disciplinary knowledge of } \\
\text { PSA }\end{array}$ & $\begin{array}{l}\text { By no means agree } \\
\text { Little agree } \\
\text { Moderately agree } \\
\text { Somewhat agree } \\
\text { Totally agree }\end{array}$ & $\begin{array}{l}11 \\
33 \\
0 \\
0 \\
0\end{array}$ & $\begin{array}{l}15.7 \% \\
47.1 \% \\
0.0 \% \\
0.0 \% \\
0.0 \%\end{array}$ & $\begin{array}{l}12 \\
14 \\
0 \\
0 \\
0\end{array}$ & $\begin{array}{l}17.1 \% \\
20.0 \% \\
0.0 \% \\
0.0 \% \\
0.0 \%\end{array}$ & $\begin{array}{l}23 \\
47 \\
0 \\
0 \\
0\end{array}$ & $\begin{array}{l}32.9 \% \\
77.1 \% \\
0.0 \% \\
0.0 \% \\
0.0 \%\end{array}$ & 3.315 & 1 & 0.069 \\
\hline Design a school team training plan & $\begin{array}{l}\text { By no means agree } \\
\text { Little agree } \\
\text { Moderately agree } \\
\text { Somewhat agree } \\
\text { Totally agree }\end{array}$ & $\begin{array}{l}12 \\
32 \\
0 \\
0 \\
0 \\
\end{array}$ & $\begin{array}{l}17.1 \% \\
45.7 \% \\
0.0 \% \\
0.0 \% \\
0.0 \% \\
\end{array}$ & $\begin{array}{l}10 \\
16 \\
0 \\
0 \\
0 \\
\end{array}$ & $\begin{array}{l}14.3 \% \\
22.9 \% \\
0.0 \% \\
0.0 \% \\
0.0 \% \\
\end{array}$ & $\begin{array}{l}22 \\
48 \\
0 \\
0 \\
0 \\
\end{array}$ & $\begin{array}{l}31.4 \% \\
68.6 \% \\
0.0 \% \\
0.0 \% \\
0.0 \% \\
\end{array}$ & 0.949 & 1 & 0.330 \\
\hline Organizing a school sport's event & $\begin{array}{l}\text { By no means agree } \\
\text { Little agree } \\
\text { Moderately agree } \\
\text { Somewhat agree } \\
\text { Totally agree }\end{array}$ & $\begin{array}{l}15 \\
29 \\
0 \\
0 \\
0 \\
\end{array}$ & $\begin{array}{l}21.4 \% \\
41.4 \% \\
0.0 \% \\
0.0 \% \\
0.0 \% \\
\end{array}$ & $\begin{array}{l}15 \\
11 \\
0 \\
0 \\
0\end{array}$ & $\begin{array}{l}21.4 \% \\
15.7 \% \\
0.0 \% \\
0.0 \% \\
0.0 \% \\
\end{array}$ & $\begin{array}{l}30 \\
40 \\
0 \\
0 \\
0\end{array}$ & $\begin{array}{l}42.9 \% \\
57.1 \% \\
0.0 \% \\
0.0 \% \\
0.0 \% \\
\end{array}$ & 3.717 & 1 & 0.054 \\
\hline $\begin{array}{l}\text { Assume an arbitration task in an optional } \\
\text { sport }\end{array}$ & $\begin{array}{l}\text { By no means agree } \\
\text { Little agree } \\
\text { Moderately agree } \\
\text { Somewhat agree } \\
\text { Totally agree }\end{array}$ & $\begin{array}{l}22 \\
22 \\
0 \\
0 \\
0 \\
\end{array}$ & $\begin{array}{l}31.4 \% \\
31.4 \% \\
0.0 \% \\
0.0 \% \\
0.0 \% \\
\end{array}$ & $\begin{array}{l}15 \\
11 \\
0 \\
0 \\
0\end{array}$ & $\begin{array}{l}21.4 \% \\
15.7 \% \\
0.0 \% \\
0.0 \% \\
0.0 \% \\
\end{array}$ & $\begin{array}{l}37 \\
33 \\
0 \\
0 \\
0\end{array}$ & $\begin{array}{l}52.9 \% \\
47.1 \% \\
0.0 \% \\
0.0 \% \\
0.0 \% \\
\end{array}$ & 0.388 & 1 & 0.533 \\
\hline $\begin{array}{l}\text { Contributing to the sports students' } \\
\text { orientation. }\end{array}$ & $\begin{array}{l}\text { By no means agree } \\
\text { Little agree } \\
\text { Moderately agree } \\
\text { Somewhat agree } \\
\text { Totally agree }\end{array}$ & $\begin{array}{l}20 \\
24 \\
0 \\
0 \\
0 \\
\end{array}$ & $\begin{array}{l}28.6 \% \\
34.3 \% \\
0.0 \% \\
0.0 \% \\
0.0 \% \\
\end{array}$ & $\begin{array}{l}20 \\
6 \\
0 \\
0 \\
0 \\
\end{array}$ & $\begin{array}{l}28.6 \% \\
8.6 \% \\
0.0 \% \\
0.0 \% \\
0.0 \% \\
\end{array}$ & $\begin{array}{l}40 \\
30 \\
0 \\
0 \\
0 \\
\end{array}$ & $\begin{array}{l}57.1 \% \\
42.9 \% \\
0.0 \% \\
0.0 \% \\
0.0 \% \\
\end{array}$ & 6.608 & 1 & 0.010 \\
\hline Online Learning & $\begin{array}{l}\text { By no means agree } \\
\text { Little agree } \\
\text { Moderately agree } \\
\text { Somewhat agree } \\
\text { Totally agree }\end{array}$ & $\begin{array}{l}19 \\
25 \\
0 \\
0 \\
0 \\
\end{array}$ & $\begin{array}{l}27.1 \% \\
35.7 \% \\
0.0 \% \\
0.0 \% \\
0.0 \% \\
\end{array}$ & $\begin{array}{l}13 \\
13 \\
0 \\
0 \\
0\end{array}$ & $\begin{array}{l}18.6 \% \\
18.6 \% \\
0.0 \% \\
0.0 \% \\
0.0 \% \\
\end{array}$ & $\begin{array}{l}32 \\
38 \\
0 \\
0 \\
0 \\
\end{array}$ & $\begin{array}{l}45.7 \% \\
54.3 \% \\
0.0 \% \\
0.0 \% \\
0.0 \% \\
\end{array}$ & 0.306 & 1 & 0.580 \\
\hline Other & $\begin{array}{l}\text { By no means agree } \\
\text { Little agree } \\
\text { Moderately agree } \\
\text { Somewhat agree } \\
\text { Totally agree }\end{array}$ & $\begin{array}{l}41 \\
3 \\
0 \\
0 \\
0\end{array}$ & $\begin{array}{l}58.6 \% \\
4.3 \% \\
0.0 \% \\
0.0 \% \\
0.0 \%\end{array}$ & $\begin{array}{l}25 \\
1 \\
0 \\
0 \\
0\end{array}$ & $\begin{array}{l}35.7 \% \\
1.4 \% \\
0.0 \% \\
0.0 \% \\
0.0 \%\end{array}$ & $\begin{array}{l}66 \\
4 \\
0 \\
0 \\
0\end{array}$ & $\begin{array}{l}94.3 \% \\
5.7 \% \\
0.0 \% \\
0.0 \% \\
0.0 \%\end{array}$ & 0.268 & 1 & 0.605 \\
\hline
\end{tabular}


TABLE III. DESIGN's PARAMETERS EXPECTED FROM THE FP@STAPS DEVICE

\begin{tabular}{|c|c|c|c|c|c|c|c|c|c|c|}
\hline & & \multicolumn{6}{|c|}{ Group } & \multirow{2}{*}{\multicolumn{3}{|c|}{ Chi-square test 2}} \\
\hline & & \multicolumn{2}{|c|}{ Hybrid } & \multicolumn{2}{|c|}{ Distanced } & \multicolumn{2}{|c|}{ Total } & & & \\
\hline & & $\mathrm{N}$ & $\%$ & $\mathrm{~N}$ & $\%$ & $\mathrm{~N}$ & $\%$ & Khi 2 & dll & $\mathrm{p}$ \\
\hline \multirow{2}{*}{ Explain some concepts in the course } & Non & 10 & $14,3 \%$ & 6 & $8,6 \%$ & 16 & $22,9 \%$ & & & \\
\hline & Oui & 34 & $48,6 \%$ & 20 & $28,6 \%$ & 54 & $77,1 \%$ & 0.001 & 1 & 0.973 \\
\hline \multirow{2}{*}{$\begin{array}{l}\text { Highlight the educational activities' } \\
\text { objectives }\end{array}$} & Non & 18 & $25,7 \%$ & 25 & $35,7 \%$ & 43 & $61,4 \%$ & & & \\
\hline & Oui & 26 & $37,1 \%$ & 1 & $1,4 \%$ & 27 & $38,6 \%$ & 21.051 & 1 & 0.000 \\
\hline \multirow{2}{*}{ To help solving technical problems } & Non & 13 & $18,6 \%$ & 9 & $12,9 \%$ & 22 & $31,4 \%$ & & & \\
\hline & Oui & 31 & $44,3 \%$ & 17 & $24,3 \%$ & 48 & $68,6 \%$ & 0.195 & 1 & 0.659 \\
\hline \multirow{2}{*}{$\begin{array}{l}\text { To help resolving conflicts within the } \\
\text { group }\end{array}$} & Non & 31 & $44,3 \%$ & 21 & $30,0 \%$ & 52 & $74,3 \%$ & & & \\
\hline & Oui & 13 & $18,6 \%$ & 5 & $7,1 \%$ & 18 & $25,7 \%$ & 0.910 & 1 & 0.340 \\
\hline \multirow{2}{*}{ To give works' assessment } & Non & 31 & $44,3 \%$ & 15 & $21,4 \%$ & 46 & $65,7 \%$ & & & \\
\hline & Oui & 13 & $18,6 \%$ & 11 & $15,7 \%$ & 24 & $34,3 \%$ & 1.181 & 1 & 0.277 \\
\hline \multirow{2}{*}{ Other } & Non & 43 & $61,4 \%$ & 25 & $35,7 \%$ & 68 & $97,1 \%$ & & & \\
\hline & Oui & 1 & $1,4 \%$ & 1 & $1,4 \%$ & 2 & $2,9 \%$ & 0.146 & 1 & 0.703 \\
\hline
\end{tabular}

TABLE IV. EDUCATIONAL TUTORING NEEDS

\begin{tabular}{|c|c|c|c|c|c|c|c|c|c|}
\hline \multirow{3}{*}{ Expected forms of FP@STAPS content } & \multicolumn{6}{|c|}{ Group } & \multirow{2}{*}{\multicolumn{3}{|c|}{ Chi-square test 2}} \\
\hline & \multicolumn{2}{|c|}{ Hybrid } & \multicolumn{2}{|c|}{ Distanced } & \multicolumn{2}{|c|}{ Total } & & & \\
\hline & $\mathrm{N}$ & $\%$ & $\mathrm{~N}$ & $\%$ & $\mathrm{~N}$ & $\%$ & Khi 2 & dll & $\mathrm{p}$ \\
\hline Text form structured in title and subtitle & 1 & $1,4 \%$ & 2 & $2,9 \%$ & 3 & $4,3 \%$ & & & \\
\hline Video sequences (capsules) & 8 & $11,4 \%$ & 4 & $5,7 \%$ & 12 & $17,1 \%$ & & & \\
\hline Images and course diagrams & 5 & $7,1 \%$ & 5 & $7,1 \%$ & 10 & $14,3 \%$ & 2.182 & 3 & 0.535 \\
\hline The four modalities at the same time & 30 & $42,9 \%$ & 15 & $21,4 \%$ & 45 & $64,3 \%$ & & & \\
\hline Sound recording & 0 & $0,0 \%$ & 0 & $0,0 \%$ & 0 & $0,0 \%$ & & & \\
\hline
\end{tabular}

\section{DISCUSSION}

The aim of our study is to identify the training needs of PES student-teachers for a SPOC (FP@STAPS), in terms of perception, design and educational tutoring.The interest of our study is to orient the design and technopedagogical piloting of this training device.For this, we compared two training groups: hybrid and distant. The first result of our study showed that all of the student-teachers declare that SPOC reduces student travel time and allows for individualized monitoring and teaching. These declarations show the positive attitude of student-teachers towards SPOCs, which can be explained by their predispositions to get involved for a good integration of these types of device in training. In this regard, some researchers have found that the key to the pedagogical integration of educational technologies lies above all in positive attitudes towards ICT (Player-Koro, 2007) [55]. Similarly, the positive representation of teachers vis-à-vis the introduction of ICT in the educational environment is certainly influenced by the progressive integration of technology in everyday life (Biaz, 2009) [3]. In addition, these positive statements regarding SPOCs lie in its spatio-temporal flexibility by allowing distant people to follow training courses without having to travel [56], as well as the diversity of teaching methods.This flexibility of the educational sequences, the articulation between training time, working time and leisure time, the pace of progression and acquisition of skills and the ability offered to each to have control of his own course of training (Blandin, Fage, Haeuw, Hellouin, Peyrondet and Primois, 2002) [57]. However, faced with these advantages of the SPOCs concerning spatio-temporal autonomy and the individualization of learning, there are challenges linked to achieving the objectives expected by these devices, in this case the low persistence rate. Indeed, the traditionally low persistence rates of ODL learners have been a subject of concern and study for many years (Scalese, 2001) [58]. Research on the factors related to abandonment or persistence has allowed some progress on this aspect of ODL (Bourdages \& Delmotte, 2001). [59] Indeed, the abandonment of studies in distance education institutions is linked to a multitude of variables, linked both to demographic factors (age, sex, civil status, ethnic or social origin, etc.) Bourdages (1996) [60], environmental factors ( family, job, material or geographic conditions, life changes, etc. (Woodley and Parlett, 1983; Billings, 1988; Powell, Conway and Ross et al., 1990) [61]-[62]-[63] and educational factors such as lessons, teaching aid, assignments, feedback, etc. (Roberts, 1984; Rekkedal, 1985; Taylor, 1986; Sweet, 1986; Sung, 1986; Garrison, 1987; Ritchie and Newby , 1989) [64]-[65]-[65][66]-[67]-[68]-[69]-[70].However, almost a third of student- 
teachers preferred a face-to-face course at RCETP than a SPOC when about $50 \%$ are unable to make this comparison. Indecision and concern about seeing the evidence of The beneficial contribution of ICT before using it themselves are the explanatory factors for this fact (Villeneuve, 2011) [71].

Faced with these findings, we suggest capitalizing on these positive representations of student teachers with regard to SPOCs, by providing close support and monitoring through quality educational tutoring reducing the dropout rate.

Our results also showed a dominance of three main skills expected by student-teachers of the SPOC: learnings' planning with dominance of hybrid group compared to distant group $(50.1 \%$ vs $30 \%)$. This fact could be explained by the increased need for student-teachers in face-to-face training, for this planning skill. It therefore constitutes, on the one hand, the trigger for their teaching-learning act, and on the other hand the element design of learning sessions during teaching placements. The competence of student's assessment, and according to the results observed, shows the importance of this axis of evaluation for student-teachers. This observation can be interpreted by the difficulty that student teachers find in an assessment.Indeed, the great difficulty in PSE to have an objective assessment is the definition of the assessment's criteria and standards (David, 2000; MacDonald \& Brooker, 1997) [72]-[73]. Added to this is the difficulty of judging heterogeneous school populations with the same evaluative framework, in very diverse material and human teaching contexts and in physical and sports activities whose differences in internal logic cannot be erased. Teachers show an attitude of doubt to the observables' choice, benchmarks and criteria that they would like relevant (Brau-Antony, 2000; David, 2000) [74]-[72]. The professional training competence for school teams $(68.6 \%)$ reflects its usefulness in the teaching task at the level of SSA (School Sports Association) sessions preparing students for school sports games. The future training content of our planned FP@STAPS system will integrate these skills into the teaching content.In addition, the finding of a statistically significant relationship of dependence between the type of group: hybrid or distant and the two skills, namely the management of learning activities and the contribution to the orientation of sports students, showed the interest given by student teachers to these two skills, which have a direct link with their daily practice.

The form and design of the SPOC (FP @ STAPS) expected by the majority of student teachers in our sample is the mixed integration of textual, pictorial and audiovisual media. This choice can be justified by the need to personalize the training path and the choice of supports (Chovino and Dallaire, 2018) [75], and by the different learners' learning styles that must be taken into account in FP@STAPS's design.

This observation requires us to integrate into our system diagrams and synthetic video capsules to respond to the visual learning style of trainees, facilitate memorization and ensure design's simple and effective ergonomics.

The need for educational tutoring mainly relates to the explanation of certain course concepts and technical problems related to the platform. This means the need to be welcomed and supported in their learning processes by facilitating the transfer of knowledge and helping them in the personal process of learning and assimilating their knowledge (Berrouk \& Jaillet, 2013; Denis, 2003; Racette, Poellhuber, \& Bourdages, 2017) [76]-[77]-[78]. Thus, two thirds of the student-teachers interviewed expressed their need for help in solving possible technical problems, which can be interpreted by the non-familiarization of student teachers with this kind of distance training via a platform comprising previously unimaginable features. This technical aid joins the nine tutorial functions proposed by Glikman (2002) [79], including help in using the tools and software of the platform. However, we found that three quarter of student-teachers refuse to resolve conflicts within the group, this result can be understood by their perceptions expressed beforehand towards the contribution of SPOCs in the individualized teaching of learners and subsequently, they do not favor collaborative work which can be a source of conflict within the class group. This statement goes against the words of (De Lièvre, Depover, Quintin, \& Decamps, 2003) [80] which highlights the tutorial function of supporting learners and setting up a climate of collaborative trust in groups of learners. In addition,the majority of student-teachers do not accept their work's online evaluation, because for them, it is an optional act and not compulsory. This surprising result, thwarts the results of certain works that have distinguished the evaluative function as essential tasks of tutors [81].

In general, the results shown in this fourth axis concerning the need for student teachers for pedagogical tutoring illustrate the technopedagogical need for student teachers which could be explained by, on the one hand, the interest accorded to training content and on the other hand to the technical inexperience of student-teachers in this kind of online training, which would push us as a pedagogical tutor of FP@STAPS to provide suitable technopedagogical help which confirms the different functions of the tutor online: disciplinary, methodological and technical, which are further explained in the words of Marie Micholet (2018) [82]. In addition, our main concern is to go beyond the framework of a single transmission of knowledge towards close support likely to ensure the motivation of student teachers to follow our online training.It should be noted that our present study is a first step to conceive FP@STAPS envisaged. It was limited to identifying needs of technopedagogical order and did not target the learners' psychological dimension.

\section{CONCLUSION}

Our study identified the student-teachers' needs for the design of a distance learning device based on the SPOC model "FP@STAPS". These needs are articulated in four axes: perception of interest of the SPOC, the needs in professional skills, the form of the SPOC and the educational tutoring. Similarly, our work underlined the importance of the courses' planning and evaluation, mixed multimedia supports: text, video capsules, images and audio files and educational tutoring.

The student teachers asked for their need for technopedagogical help relating to the resolution of the platform's technical problems used and educational objectives' clarification. These conclusions will serve us in the future 
stage of designing the device to plan a training module reserved for basic professional skills in PSE: planning, management and evaluation in PSE. By integrating various digital resources into our platform, and a appropriate tutoring mode, we will respond on the one hand, to the students' different learning styles and on the other hand, support the student-teachers while awaiting the educational objectives.

Future research axes will determine student-teachers' learning styles to have other precise data that will allow us to tailor-make our online distance training, by questioning a larger sample concerning several training centers in Morocco.

\section{ACKNOWLEDGMENT}

The authors would like to thank the director of RCETP Casablanca-Settat and PES student-teachers who enthusiastically participated in the different phases of our study.

\section{REFERENCES}

[1] Traoré D. Quel avenir pour l'usage pédagogique des TIC en Afrique subsaharienne? Cas de cinq pays membres du ROCARE. ICT Chang Mindsets Educ L'éducation À L'aide TIC Bamenda Cameroon Langaa. 2008.

[2] Redecker, C., Ala-Mutka, K., Bacigalupo, M., Ferrari, A. \& Punie, Y._(2009). Learning 2.0: the impact of web 2.0 innovations on education_and training in Europe. Séville, Espagne : Institute for Prospective_Technological Studies.

[3] Biaz A, Bennamara A, Khyati A, Talbi M. Intégration des technologies de l'information et de la communication dans le travail enseignant, état des lieux et perspectives. EpiNet Rev Électronique L'EPI. 2009;120.

[4] Maddux CD, Johnson DL. External validity and research in information technology in education. Taylor \& Francis; 2012.

[5] Collin S, Karsenti T. Usages des technologies en éducation: analyse des enjeux socioculturels. Éducation Francoph. 2013;41(1):192-210.

[6] Kaikai HA. Appropriation des Technologies de l'Information et de la Communication au sein de l'Université marocaine: Perceptions des étudiants. Rev FRANTICE. 2014;(8).

[7] Using ICT to develop literacy. Bangkok: UNESCO; 2006.

[8] Conseil Supérieur de l'Education, de la Formation et de la Recherche Scientifique "Vision stratégique de la réforme 2015-2030, Levier 12; Article $77 \mathrm{pp} \mathrm{:} 43$.

[9] El Ouidadi O, Lakdim A, Essafi K, Sendide K. Contribution à l'évaluation de l'impact de l'intégration des TICE dans l'enseignement et l'apprentissage: exemple de la division cellulaire (mitose) en deuxième année de baccalauréat sciences expérimentales. Rev Électronique L'EPI Paris. 2011.

[10] Unité Centrale de la Formation des Cadres; Curriculum d'éducation physique et sportive ; Filière de Qualification des Professeurs du Secondaire Qualifiant -Juillet 2012-.

[11] Drissi MM, Mohammed T, Mohamed K. La formation à distance, un système complexe et compliqué (Du triangle au tétraèdre pédagogique). sept 2006 [cité 4 oct 2018];(83). Disponible sur: https://www.epi.asso.fr/revue/articles/a0609b.htm.

[12] Parmentier C. L'ingénierie de formation: outils et méthodes. Paris: Ed. d'Organisation; 2008.

[13] Félix, Y. (2010). Analyse des besoins technologiques des apprenants à distance à la Télé-université (Doctoral dissertation, Télé-université).

[14] Organization for Economic Co-operation and Development [OECD] (2001). The well-being of nations: The role of human and social capital. Paris: OECD.

[15] OCDE (2004). OECD survey of upper secondary schools - Technical report. OCDE.

[16] Basque J, Lundgren-Cayrol K. Une Typologie Des Typologies Des Usages Des «Tic » En Éducation. 2003;35.
[17] Mastafi M. Intégration et usages des TIC dans le système éducatif marocain: Attitudes des enseignants de l'enseignement primaire et secondaire. 2013.

[18] Karsenti T. Favoriser la motivation et la réussite en contexte scolaire: Les TIC feront-elles mouche. Vie Pédagogique. 2003;127:27-32.

[19] Nafidi Y, Alami A, Zaki M, Afkar H. Open and Distance Learning in the Initial Education of Trainee Teachers. Int J Educ. 2015;13.

[20] Peraya D. La formation à distance: un dispositif de formation et de communication médiatisées. Une approche des processus de médiatisation et de médiation. Calidoscópio. 2006;4(3):200-204.

[21] Depover C, Karsenti T, Komis V. Enseigner avec les technologies: favoriser les apprentissages, développer des compétences. PUQ; 2007.

[22] Cleary, Christopher, Abdeljalil Akkari, and Diego Corti. "L'intégration des TIC dans l'enseignement secondaire." Formation et pratiques d'enseignement en questions 7 (2008): 29-49.

[23] Delpeyroux S, Bachelet R. Intégrer un MOOC dans un cursus de formation initiale. : 10 .

[24] Riyami B. Analyse des effets des TIC sur l'enseignement supérieur au Maroc dans un contexte de formation en collaboration avec une université française. 2018;168.

[25] Depover, C., \& Orivel, F. (2012). Les pays en développement à l'ère de l'e-learning. Institut international de planification de l'éducation (Unesco).

[26] Ahaji K, Zahim S, Badda B. Soubassements théoriques pour guider l'intégration réussie des TICE. EpNet Rev Electron L'EPI. 2012;142.

[27] Neema-Abooki PA, Neema-Abooki NR. Usability of Computers in Teaching and Learning at Tertiary-level Institutions in Uganda. Afr $\mathbf{J}$ Teach Educ. 2015;4(1).

[28] Sumande CT, Castolo CL, Comendador BEV. The ICT level of confidence of course specialists in distance education: The Polytechnic University of the Philippines experience. Turk Online J Distance Educ. 2016;17(4).

[29] Haymore Sandholtz J, Ringstaff C, OWYER DC. La classe branchée. Enseigner À L'ère Technol Paris CNDP Titre Orig Teach Technol Creat Stud-Centered Classr. 1997.

[30] Guay P-J. Les TIC et l'enseignement: un tour d'horizon. Bull Clic. 2001;41:2-5.

[31] Organisation des Nations Unies pour l'éducation, la science et la culture. (2003).Développements récents et perspectives de l'enseignement supérieur en Afrique subsaharienne au 21e siècle. Paris : Auteur.

[32] McGorry SY. Online, but on target? Internet-based MBA courses: A case study. Internet High Educ. 2002;5(2):167-175.

[33] Rasmy A, Karsenti T. Les déterminants de la motivation des enseignants en contexte de développement professionnel continu lié à l'intégration des technologies. Rev Int Technol En Pédagogie Univ J Technol High Educ. 2016;13(1):17-35.

[34] Leclerc M. Un nouveau regard sur les profils des enseignants à l'égard de l'intégration des TIC. Can J Learn Technol Rev Can L'apprentissage Technol. 2007;33(2).

[35] Depover C, Strebelle A. Un modèle et une stratégie d'intervention en matière d'introduction des TIC dans le processus éducatif. IRDP; 1997.

[36] Hutchison A, Reinking D. Teachers' perceptions of integrating information and communication technologies into literacy instruction: A national survey in the United States. Read Res Q. 2011;46(4):312-333.

[37] Karsenti, T. et Collin, S. (2013). TIC et éducation : avantages, défis et perspectives futures. Éducation et francophonie, 41(1), Numéro thématique.

[38] Livingstone S. Critical reflections on the benefits of ICT in education. Oxf Rev Educ. févr 2012;38(1):9-24.

[39] Bibeau R. Les technologies de l'information et de la communication peuvent contribuer à améliorer les résultats scolaires des élèves. Rev L'EPI. 2007;94.

[40] Labrique S, Grenier D, Labrique F. Entre savoir et savoir-être, du rôle des TIC dans le processus d'apprentissage du génie électrique: compte rendu d'innovation. Didask Paris. 2004. 
[41] Tardif, J., Intégrer les nouvelles technologies de l'information. Quel cadre pédagogique ? Paris : ESF Editeur. Collection "Pratiques et enjeux pédagogiques". 1998.

[42] Leburun M., Des technologies pour enseigner et apprendre, Paris, De Boeck Université, 2002.

[43] Karsenti, Thierry, and Clermont Gauthier. "Les TIC bouleversent-elles réellement le travail des enseignants." Formation et profession 12.3 (2006): 2-4.

[44] Ertmer PA. Addressing first-and second-order barriers to change: Strategies for technology integration. Educ Technol Res Dev. 1999;47(4):47-61.

[45] Pelgrum WJ. Obstacles to the integration of ICT in education: results from a worldwide educational assessment. Comput Educ. 2001;37(2):163-178.

[46] BECTA (2005). What the research says about barriers to the use of ICT in teaching. Becta ICT Research.

[47] Al-Alwani AES. Barriers to integrating information technology in Saudi Arabia science education. University of Kansas; 2005.

[48] Balanskat A, Blamire R, Kefala S, others. A review of studies of ICT impact on schools in Europe. Eur Sch. 2006.

[49] Becta A. A review of the research literature on barriers to the uptake of ICT by teachers. Lond UK BECTA Httppublications Becta Org Ukdisplay Cfm. 2004.

[50] Beggs TA. Influences and Barriers to the Adoption of Instructional Technology. 2000.

[51] Gomes C. Integration of ICT in science teaching: A study performed in Azores, Portugal. Recent Res Dev Learn Technol. 2005;13(3):63-71.

[52] Lazaros EJ, Rogers GE. Critical Problems Facing Technology Education: Perceptions of Indiana Teachers. J Ind Teach Educ. 2006;43(2):45-69.

[53] Schoepp K. Barriers to technology integration in a technology-rich environment. Learn Teach High Educ Gulf Perspect. 2005;2(1):1-24.

[54] Moodle H. Moodle. West Perth Aust Moodle HQ. 2018.

[55] Player-Koro C. Why teachers make use of ICT in education. In: Arbetspaper presenterat vid 10th Pre-Conference of Junior Researchers of Earli, 27-28 augusti, Budapest, Ungern. 2007.

[56] Mustapha A. Formation à distance: dispositif et gestion-. Télévision Interactive, Rabat, Maroc; 2005.

[57] Blandin B, Fage C, Haeuw F, Hellouin V, Peyrondet J, Primois C. Le $\mathrm{BA} \mathrm{BA}$ de la FOAD. In: Forum Français de la Formation à distance. 2002.

[58] Scalese ER. What Can a College Distance Education Program Do To Increase Persistence and Decrease Attrition? J Instr Deliv Syst. 2001;15(3):16-20.

[59] Bourdages L, Delmotte C. La persistance aux études universitaires à distance. Int J E-Learn Distance Educ Int E-Learn Form À Distance. 2007;16(2):23-36.

[60] Bourdages L. La persistance et la non-persistance aux études universitaires sur campus et en formation à distance. Distances. 1996;1(1):51-68.

[61] Woodley A, Parlett M. Student drop-out. Teach Distance. 1983;24:2-23.

[62] Billings, D.M. (1988). A conceptual model of nontraditional undergraduate student attrition. Review of Educational Research, 55, 485-540.
[63] Powell R, Conway C, Ross L. Effects of student predisposing characteristics on student success. Int J E-Learn Distance Educ Int ELearn Form À Distance. 1990;5(1):5-19.

[64] Roberts D. Ways and means of reducing early student drop-out rates. Distance Educ. 1984;5(1):50-71.

[65] Rekkedal T. Introducing the Personal Tutor/Counsellor in the System of Distance Education. Project Report 2. ERIC; 1985.

[66] Taylor JC. Student persistence in distance education: a cross-cultural multi-institutional perspective. Distance Educ. 1986;7(1):68-91.

[67] Sweet R. Student dropout in distance education: An application of Tinto's model. Distance Educ. 1986;7(2):201-213.

[68] Sung N. Perceptions of program and learning environment as determinants of persistence and poststudy attitudes in adult distance learning. University Microfilms; 1986.

[69] Garrison DR. Researching dropout in distance education. Distance Educ. 1987;8(1):95-101.

[70] Ritchie H, Newby TJ. Instruction: Classroom lecture/discussion vs. live televised instruction: A comparison of effects on student performance, attitude, and interaction. Am J Distance Educ. 1989;3(3) :36-45.

[71] Villeneuve SP. L'évaluation de la compétence professionnelle des futurs maitres du Québec à intégrer les technologies de l'information et des communications (TIC): maitrise et usages. 2011.

[72] David B. Éducation physique et sportive: la certification au baccalauréat. Institut national de recherche pédagogique; 2000.

[73] Macdonald D, Brooker R. Assessment issues in a performance-based subject: A case study of physical education. Stud Educ Eval. 1997;23(1):83-102.

[74] Brau-Antony S. Étude des référentiels d'évaluation: l'exemple du volley-ball. L'Education Phys Sport Certif Au Bac. 2000;57-76.

[75] Chovino, L. et Dallaire, F. (2018). Guide sur la personnalisation des apprentissages en formation à distance pancanadienne francophone. Montréal, QC: REFAD.

[76] Berrouk S, Jaillet A. Les fonctions tutorales: pour un déséquilibre dynamique. Distances Médiations Savoirs Distance Mediat Knowl. 2013;1(2).

[77] Denis B. Quels rôles et quelle formation pour les tuteurs intervenant dans des dispositifs de formation à distance? Distances Savoirs. 2003;1(1):19-46.

[78] Racette N, Poellhuber B, Bourdages-Sylvain M-P. Quelles sont les caractéristiques de l'emploi et du travail des tuteurs en formation ouverte et à distance? Distances Médiations Savoirs Distance Mediat Knowl. 2017;(18).

[79] Glikman V. Des cours par correspondance au" e-learning"[From correspondence courses to" e-learning"]. Paris Press Univ Fr. 2002.

[80] De Lièvre B, Quintin J. et Decamps S. 2003. In: Les représentations a priori et a posteriori du tutorat à distance Conférence EIAH. 2003. p. 115-126.

[81] De Lièvre B, Depover C, Quintin J-J, Decamps S. Les représentations a priori et a posteriori qu'ont les apprenants du rôle du tuteur dans une formation à distance. In 2003.

[82] Marie Micholet. Un tutorat transversal à distance et en ligne pour l'université. Linguistique. Université Paul Valéry - Montpellier III, 2018. Français. ffNNT : 2018MON30031ff. fftel-02019880f. 